Division of Geological \& Geophysical Surveys

PRELIMINARY INTERPRETIVE REPORT 2009-3

\title{
A RECONNAISSANCE VIEW OF AN UNNAMED FAULT NEAR CAPPS GLACIER, NORTHWESTERN COOK INLET BASIN, AND ITS POTENTIAL AS A REGIONAL-SCALE, BASIN-CONTROLLING STRUCTURE
}

by

Robert J. Gillis, David L. LePain, Kenneth D. Ridgway, and Emily S. Finzel

May 2009

THIS REPORT HAS NOT BEEN REVIEWED FOR TECHNICAL CONTENT (EXCEPT AS NOTED IN TEXT) OR FOR CONFORMITY TO THE EDITORIAL STANDARDS OF DGGS.

Released by

STATE OF ALASKA

DEPARTMENT OF NATURAL RESOURCES

Division of Geological \& Geophysical Surveys 3354 College Rd.

Fairbanks, Alaska 99709-3707 



\section{CONTENTS}

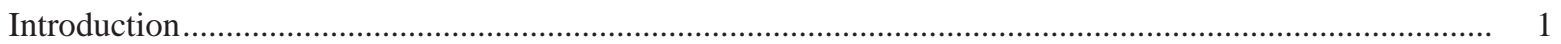

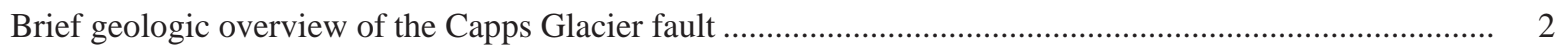

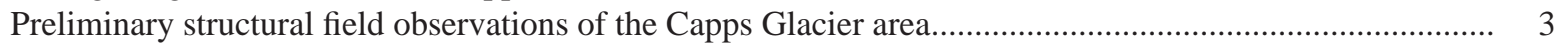

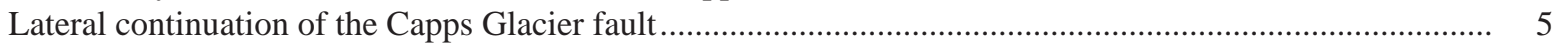

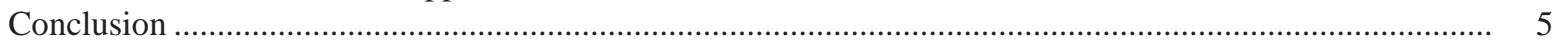

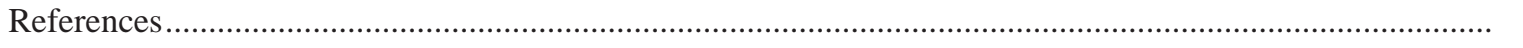

\section{FIGURES}

Figure 1. Simplified map of south-central Alaska emphasizing the regional tectonic elements.................. 1

2. Geologic map of the 2007-2008 DGGS study area along the northwestern margin of the Cook Inlet forearc basin showing bedrock distribution ......................................................... 2

3. View looking to the northeast at generally well-exposed rock cut by the Capps Glacier fault ...... 3

4. Southern hemisphere projection stereogram and rose diagram representations of limited fracture orientations measured from granitic field exposures near Capps Glacier fault

5. View looking southwest along Capps Glacier fault at map-scale fractures common throughout

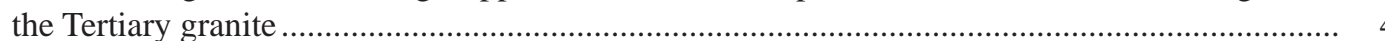

6. Interpreted and uninterpreted aerial photographs centered on the only documented exposure

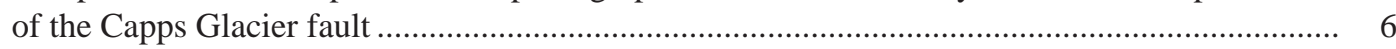

7. Topographic map of Mount Susitna area .......................................................................... 7

8. Aeromagnetic anomaly map of western Cook Inlet-southern Alaska Range superimposing topography and showing the interpreted position of the Telaquana fault relative to the projection of the Capps Glacier fault 



\title{
A RECONNAISSANCE VIEW OF AN UNNAMED FAULT NEAR CAPPS GLACIER, NORTHWESTERN COOK INLET BASIN, AND ITS POTENTIAL AS A REGIONAL-SCALE, BASIN-CONTROLLING STRUCTURE
}

\author{
by
}

Robert J. Gillis ${ }^{1}$, David L. LePain ${ }^{1}$, Kenneth D. Ridgway², and Emily S. Finzel ${ }^{2}$

\section{INTRODUCTION}

The Cook Inlet forearc basin, a hydrocarbon province containing nearly 8,200 billion cubic feet (Bcf) of natural gas and more than 2,400 million barrels of oil (MMBO) reserves (Alaska Division of Oil \& Gas [DOG], 2007), is bounded to the northwest by a system of regional-scale transpressional, down-to-the-southeast faults that have exerted a fundamental control on basin geometry and stratigraphic architecture. The steeply-dipping fault system composed of the Castle Mountain, Bruin Bay, and Lake Clark faults (fig. 1) cuts a basinward-thickening package of Cenozoic-age terrestrial basin fill up to 7,620 m thick (Swenson, 2003). A fourth, unnamed and poorly expressed fault farther outboard of the basin to the northwest, referred to here as the Capps Glacier fault, has until now received little attention. However, preliminary results from reconnaissance field studies led by the Alaska Division of Geological \& Geophysical Surveys (DGGS) in 2007 and 2008 suggest that the Capps Glacier fault could be the westernmost basin-controlling structure of the Cook Inlet forearc basin.

Until now, the northwesternmost recognized fault of regional significance bounding Cook Inlet basin is the Pleistocene-age or older (Schmoll and Yehle, 1987) Lake Clark fault. The Lake Clark fault links to the northwest with the Holocene (Detterman and others, 1974; Haeussler and others, 2002) Castle Mountain fault (fig. 1) and locally places Late Cretaceous-Early Tertiary granitoids against terrestrial sedimentary rocks of the Kenai Group (Barnes, 1966; Magoon and others, 1976). The Capps Glacier fault was first reported by Barnes in 1966 and is located approximately $18 \mathrm{~km}$ to the northwest of the trace of the Lake Clark fault. The fault is only exposed over a short interval, but juxtaposes exhumed Late Paleocene-age plutonic rock against Paleocene-Eocene Cook Inlet basin fill and may represent a regional structure bounding the northwesternmost part of the basin (fig. 2).

Figure 1. Simplified map of southcentral Alaska emphasizing the regional tectonic elements. Highlighted polygon outlines the 2007-2008 DGGS study location.

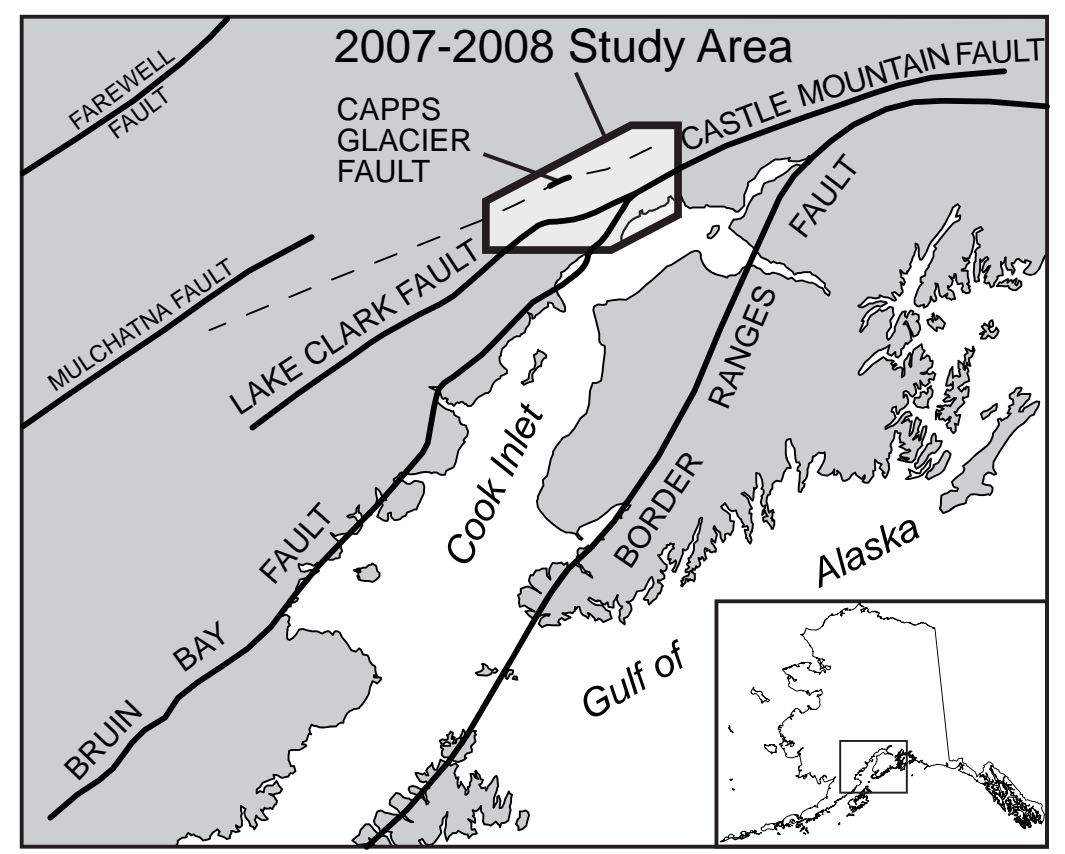

${ }^{1}$ Alaska Division of Geological \& Geophysical Surveys, 3354 College Rd., Fairbanks Alaska 99709-3707; email for R.J. Gillis: robert.gillis@alaska.gov

${ }^{2}$ Department of Earth and Atmospheric Sciences, Purdue University, West Lafayette, Indiana 47907 


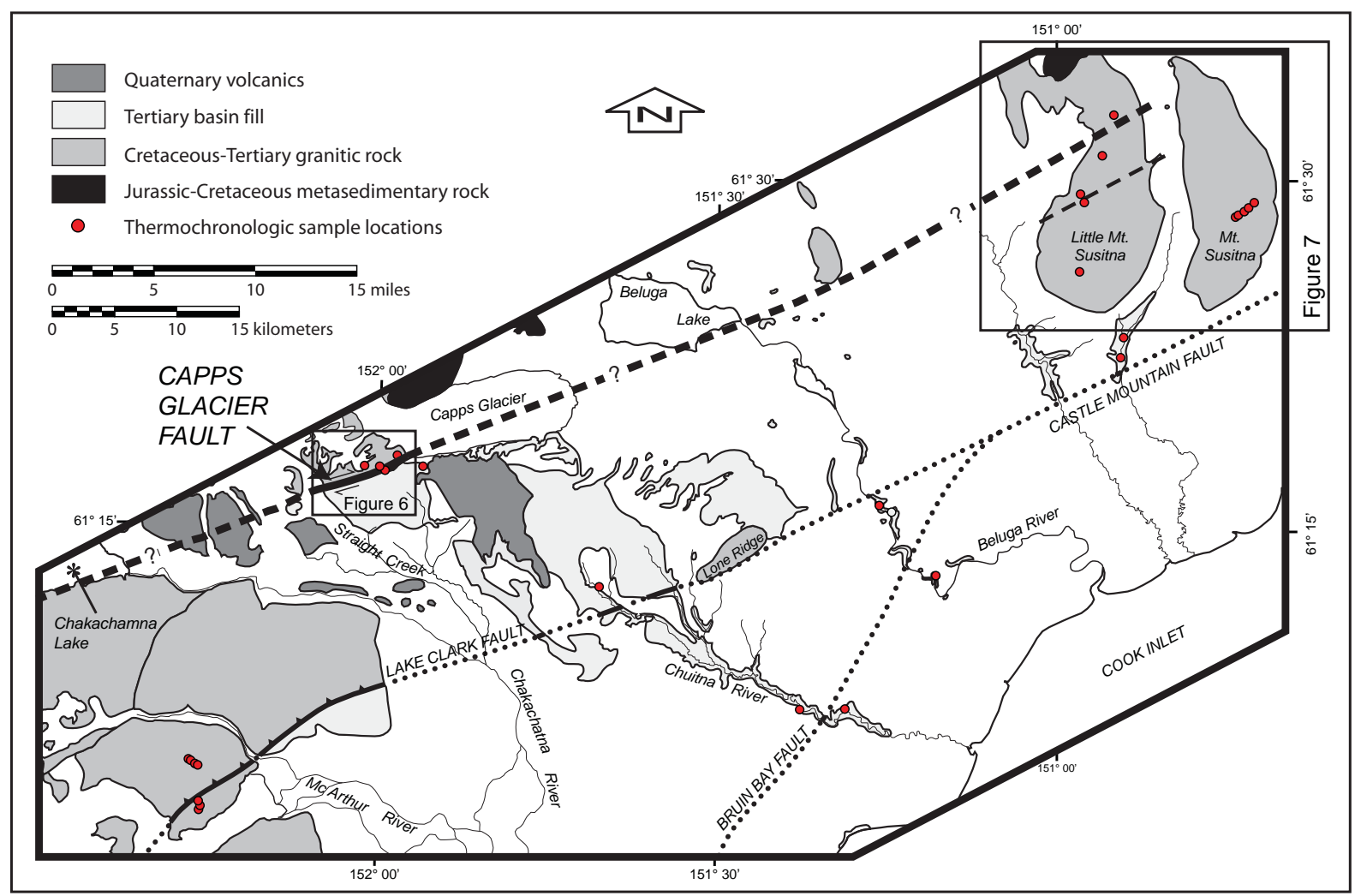

Figure 2. Geologic map simplified from Magoon and others (1976) of the 2007-2008 DGGS study area along the northwestern margin of the Cook Inlet forearc basin showing bedrock distribution (shaded polygons). Potential continuation of Capps Glacier fault (thick dashed line) shown relative to the major tectonic structures in the area. Red circles denote thermochronological sample locations.

During two weeks of each of the summers of 2007 and 2008, the Alaska Division of Geological \& Geophysical Surveys (DGGS) and the Alaska Division of Oil \& Gas (DOG), in collaboration with Purdue University and the U.S. Geological Survey (USGS), conducted reconnaissance field studies in the area of the Capps Glacier and Beluga River areas. The focus in this region is part of a larger basin-wide outcrop study to assess the controls on basin development and stratigraphic architecture of the prospective Cook Inlet forearc basin.

Southeast of Mount Spurr, the Capps Glacier fault is exposed only along a short, approximately 4.5-km-long interval between Straight Creek to the southwest and Capps Glacier to the northeast (fig. 2). Preliminary field observations suggest the Capps Glacier fault accommodates principally strike-slip, or oblique-slip, and could possibly extend northeastward as far as the Susitna Basin. There is perhaps more compelling evidence that the Capps Glacier fault or related faults may continue a significant distance to the southwest, possibly making it part of a regional-scale structure $\sim 180-240 \mathrm{~km}$ in length. Proposed DGGS field studies and geologic mapping of the Capps Glacier area in 2009 and 2010 will focus in part on assessing the sense of motion, magnitude of slip, and exploring the lateral extent of the Capps Glacier fault.

\section{BRIEF GEOLOGIC OVERVIEW OF THE CAPPS GLACIER FAULT}

Although the Capps Glacier fault has been recognized for more than 40 years, little has been published it (Barnes, 1966; Magoon and others, 1976). Geological relationships pertaining to the fault based on available literature, including original 1:250,000-scale mapping by Barnes (1966), are highlighted below.

The Capps Glacier fault places Late Paleocene granitic rock to the northwest against Paleocene-Eocene basin-fill deposits, Cretaceous-Jurassic metavolcanic basement rock to the southeast along a steeply northwestward-dipping plane. The juxtaposition of older intrusive rocks over younger strata implies that some component of up-to-the-southeast dip-slip (Barnes, 1966) or strike-slip motion was accommodated by the fault since early Cenozoic time. The 58.7 Ma quartz monzonite (Reed and Lanphere, 1972) in the upthrown block intrudes undivided 
Cretaceous-Jurassic metavolcanic rocks. Undivided Cretaceous-Jurassic metavolcanic rocks also occurring in the downthrown block are overlain by more than $670 \mathrm{~m}$ of proximal terrestrial strata (Barnes, 1966; Adkison and others, 1975) assigned to the West Foreland and Tyonek formations (Detterman and others, 1976; Magoon and others, 1976). These deposits are regionally significant and serve as principal petroleum reservoir rocks at depth within Cook Inlet basin (Calderwood and Fackler, 1972). Plant micro- and macro-fossils loosely constrain the age of the Tertiary deposits between late Paleocene and early to late Miocene times (Wolfe and others, 1966; Adkison and others, 1975). Intrusive conglomerate clasts approaching $1 \mathrm{~m}$ in diameter in these strata (Adkison and others, 1975; Finzel and others, 2009; LePain and others, 2008) indicate a proximal source. The overlapping ages between exhumed intrusive rocks in the upthrown block and proximal strata containing intrusive clasts in the downthrown block directly southeast of the fault suggest a relationship between motion along the Capps Glacier fault and sedimentation along the northwestern edge of Cook Inlet basin.

\section{PRELIMINARY STRUCTURAL FIELD OBSERVATIONS OF THE CAPPS GLACIER AREA}

Helicopter-supported field reconnaissance of the Capps Glacier fault area by DGGS field parties in August 2007 reveals excellent exposures of rocks immediately to the northwest and southeast of the fault and locally to within 20 to $30 \mathrm{~m}$ of the fault trace (fig. 3). Preliminary observations indicate that the Capps Glacier fault is likely a high-angle fault accommodating mostly strike- or oblique-slip motion in a transpressional and/or transtensional setting. Although limited landings along the fault trace did not yield a view of the actual contact, the near-linear expression of the fault plane as it intersects topography suggests a very steeply northwestward-dipping surface

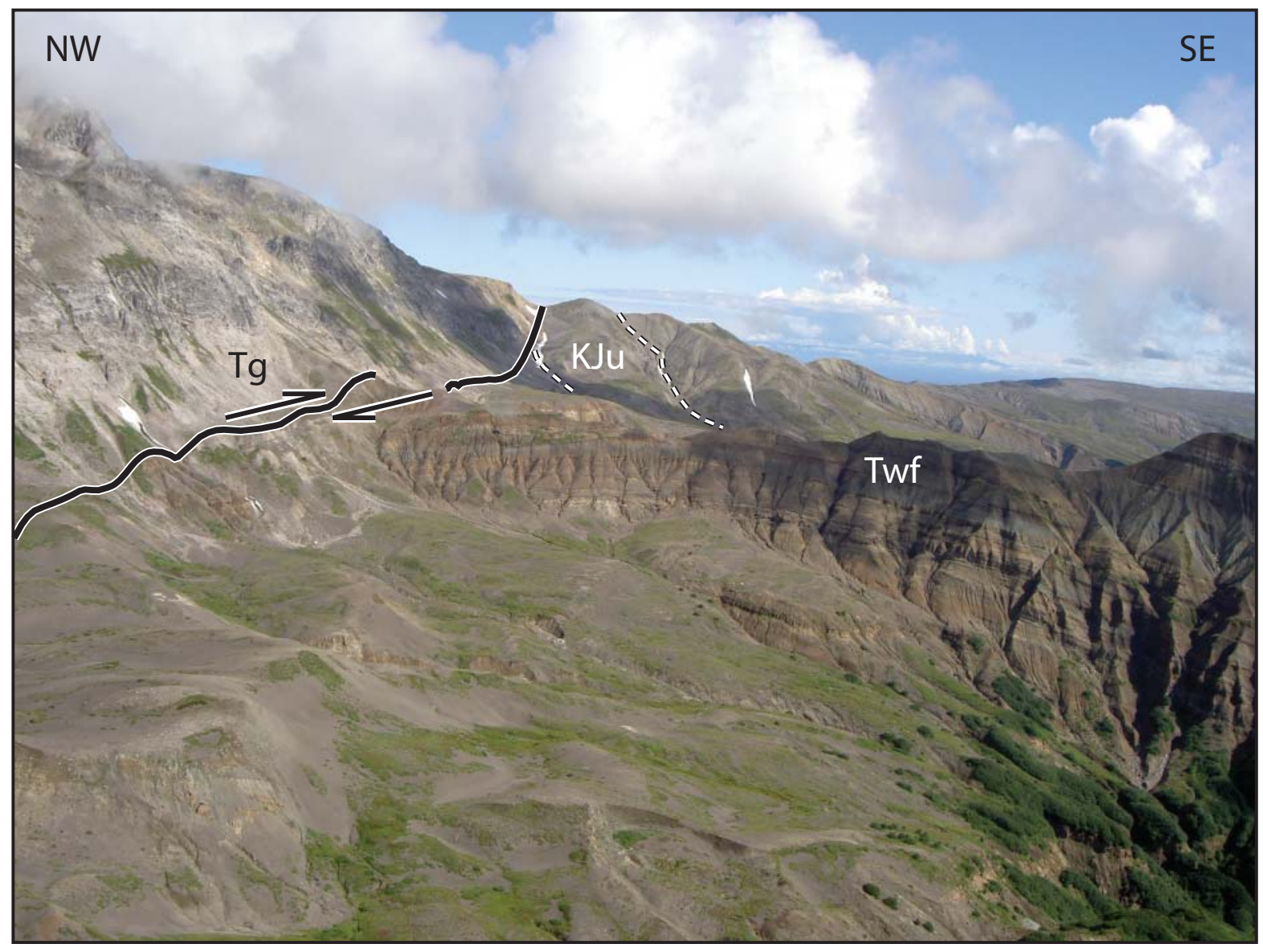

Figure 3. View looking to the northeast at generally well-exposed rock cut by the Capps Glacier fault (white-outlined black line). Rocks in the upper left of the image are early Cenozoic quartz monazite. Gently deformed strata in the center and right of the image (Twf) are composed of Cenozoic clastic basin fill of the West Foreland Formation. 
trending at approximately $240^{\circ}$. Likewise, the sense of motion along the fault remains uncertain, but preliminary field observations, aerial photo interpretation, and geologic map relationships suggest a significant component of right-lateral strike-slip faulting. Limited measurements of outcrop-scale fractures and narrow shear zones within the medium to coarse grain, and typically non-foliated quartz monzonite yielded predominately east-west orientations with steep dips (fig. 4). Where observed, slip lineations plunge at angles of $36^{\circ}$ or less, indicating local oblique slip along shear surfaces. Marginally defined chatter marks observed on a single shear surface are consistent with oblique dextral motion. Mesoscopically, the rock exhibits a conspicuous set of east-west-trending sub-vertical fractures that produce closely spaced, deep, parallel furrows and

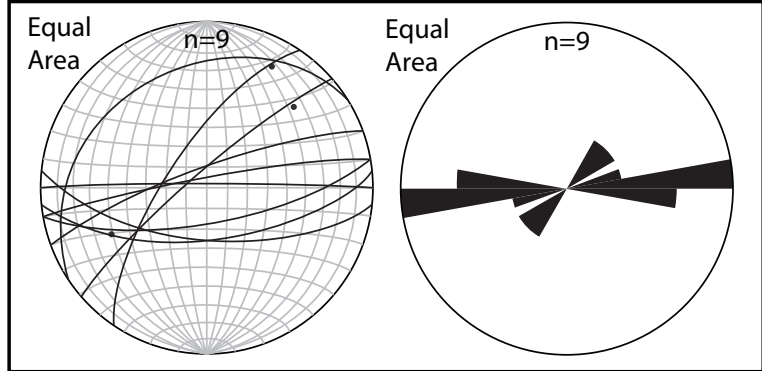

Figure 4. Southern hemisphere projection stereogram and rose diagram representations of limited fracture orientations measured from granitic field exposures near Capps Glacier fault. Orientations are generally steeply dipping, east- and northeast-trending, with low-angle slip lineations. narrow ridges of similar orientation to outcrop-scale fractures (fig. 5). Collectively, mesoscopic fault and fracture orientations along with outcrop-scale shear-plane orientations and shear indicators suggest right-lateral oblique slip within a transpressive or transtensive setting. Evidence of transpressional and/or transtensional deformation is also expressed in the Cenozoic-age deposits in the downthrown fault block to the southeast.

West Foreland Formation strata in the downthrown block are truncated at a high angle to the northwest by the Capps Glacier fault, but are deformed by contractional/transpressional and transtensional structures directly southeast of the fault (fig. 6). Cenozoic basin-fill deposits unconformably overlie highly deformed Cretaceous-Jurassic metavolcanic rock locally near the fault contact. The Cenozoic strata are in turn gently deformed by open folding and common small-scale faulting. Discontinuous anticline fold hinges directly southeast of the Capps Glacier fault are oriented approximately parallel to the trace of the fault and appear to be bounded to the northeast and

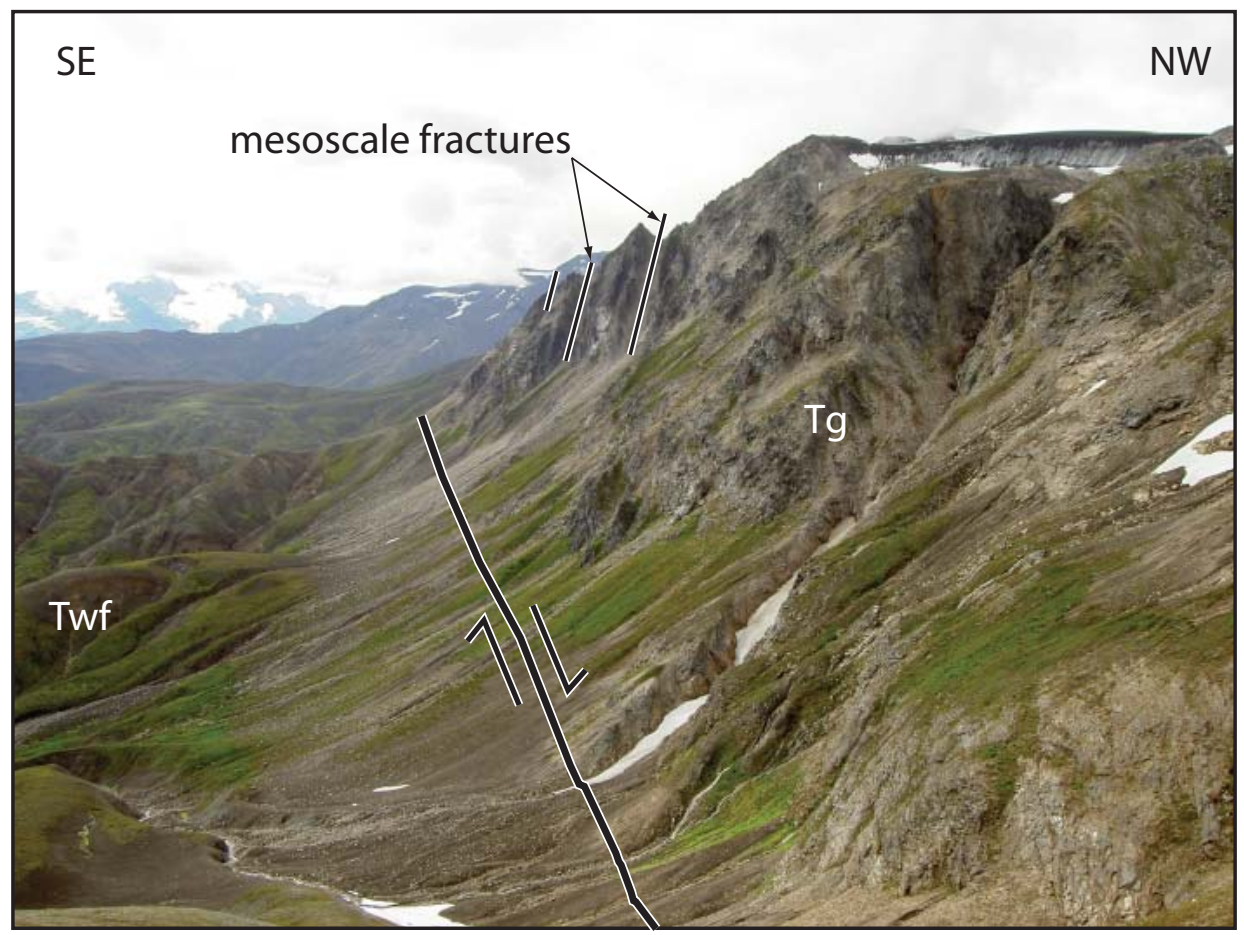

Figure 5. View looking southwest along Capps Glacier fault at map-scale fractures common throughout the Tertiary granite. Most common fracture orientation is 30 degrees in a clockwise direction to the fault. 
southwest by smaller-scale transtensional faults (fig. 6). The anticlines are tentatively interpreted to result from reverse or oblique-reverse motion along the Capps Glacier fault. The fold axis of a single, conspicuous, syncline basinward of the anticlines is oriented approximately $20^{\circ}$ counterclockwise to the anticline fold axes and Capps Glacier fault and is truncated to the northeast and southwest by east-southeast-trending transtensional faults (fig. 6). Faults within the Cenozoic basin fill dip steeply north-northeastward and south-southwestward and exhibit mostly normal, oblique-normal, strike-slip, and, rarely, reverse displacement. Kinematic indicators include drag folding of strata at fault interfaces, small-scale folding near fault contacts, and groove lineations on fault surfaces. The faults truncate fold limbs at oblique angles to their fold axes, suggesting that, at least locally, the basin margin may have experienced polyphase transpressive and transtensive deformation (see Finzel and others [2009] for a more detailed discussion). Proposed 1:63,360-scale geologic mapping of the area in 2009 and 2010 will focus on characterizing the geologic structures in the Capps Glacier area and exploring structural and kinematic relationships between deformed granitic, Cretaceous-Jurassic basement, and Tertiary sedimentary rocks.

The magnitude of displacement accommodated by the Capps Glacier fault is uncertain. However, a minimum value of right-lateral separation of $\sim 3.5 \mathrm{~km}$ is inferred along the trace of the Capps Glacier fault based on the relative positions of undivided Jurassic-Cretaceous metasedimentary rocks cut by the fault to the southeast and the same metasedimentary wall rocks intruded by the quartz monzonite to the north (fig. 6). Conceivably, the magnitude of right-lateral separation could be an order of magnitude greater assuming the Capps Glacier fault continues southwestward into the Chakachamna valley near Chakachamna Lake as projected (fig. 2). Restoring the quartz monzonite north of the fault southwestward along the projection of the fault to a quartz monzonite of the same age (Reed and Lanphere, 1969) on the south side of the drainage could call for as much as $20 \mathrm{~km}$ of horizontal motion. However, Quaternary sedimentary cover and volcanic deposits from nearby Mount Spurr obscure the southern quartz monzonite-fault contact, precluding the identification of a piercing point.

\section{LATERAL CONTINUATION OF THE CAPPS GLACIER FAULT}

Determining if the Capps Glacier fault continues beyond Straight Creek to the southwest and the Capps Glacier to the northeast is hindered by a preponderance of granitic rock to the southwest and Quaternary deposits to the northeast that either complicate the identification of, or completely cover, pre-Pleistocene faults. The closest significant bedrock exposures northeastward along strike of the Capps Glacier fault are granitic ridges of Mt. Susitna and Little Mount Susitna $\sim 40 \mathrm{~km}$ distant (fig. 2). Northwest-oriented topographic lineaments and low saddles across Little Mount Susitna, approximately along strike of the fault, suggest local shearing of the granitic body (fig. 7). Across a low saddle near the northern end of Little Mount Susitna, fine-grained, non-foliated rocks to the north differ from medium-grained, foliated rocks to the south and exhibit highly shattered grains in thin section. However, new unpublished ${ }^{40} \mathrm{Ar} /{ }^{39} \mathrm{Ar}$ ages of the rocks on both sides of the saddle are identical within error, suggesting that any fault offset across the saddle is minor in scale. These ages and additional new ${ }^{40} \mathrm{Ar} /{ }^{39} \mathrm{Ar}$ ages, apatite fission-track, and zircon U-Pb data will be published in a future report.

To the southwest across Straight Creek, the Capps Glacier fault projects into the mouth of the Chakachamna drainage. At this location, Reed and Lanphere (1969) report well-developed foliation not observed elsewhere in Cretaceous-age and younger intrusive rocks in the western Alaska Range. Farther to the southwest, Haeussler and Saltus (2004) infer the presence of a fault accommodating $\sim 11 \mathrm{~km}$ of right-lateral slip, the Telaquana fault, northwest of Lake Clark, based on interpretation of residual total field magnetic anomalies (fig. 8). The Telaquana fault is interpreted to extend northeastward more than $100 \mathrm{~km}$, skirting Telaquana Pass into the headwaters of the Chakachamna drainage approximately along strike and within $30 \mathrm{~km}$ of the Capps Glacier fault (fig. 8). If the faults are related, then a Capps-Telaquana fault system would represent a regionally significant structure more than $135 \mathrm{~km}$ long with possibly $11 \mathrm{~km}$ of right-lateral offset.

\section{CONCLUSION}

Reconnaissance field investigation of the Capps Glacier area in 2007 and 2008 by DGGS and DOG in collaboration with Purdue University and the USGS, has identified the Capps Glacier fault as possibly a regional-scale, dextral structure that may have exerted a control on Cook Inlet forearc basin development during early Cenozoic time. Thermochronologic and geochronologic analyses of rocks in the upthrown and downthrown blocks of the Capps Glacier fault, along with proposed geologic mapping of the Capps Glacier area in the summer of 2009 and 2010, will further our understanding of the fault's sense of slip and slip magnitude, and perhaps provide constraints on the timing of activity. 

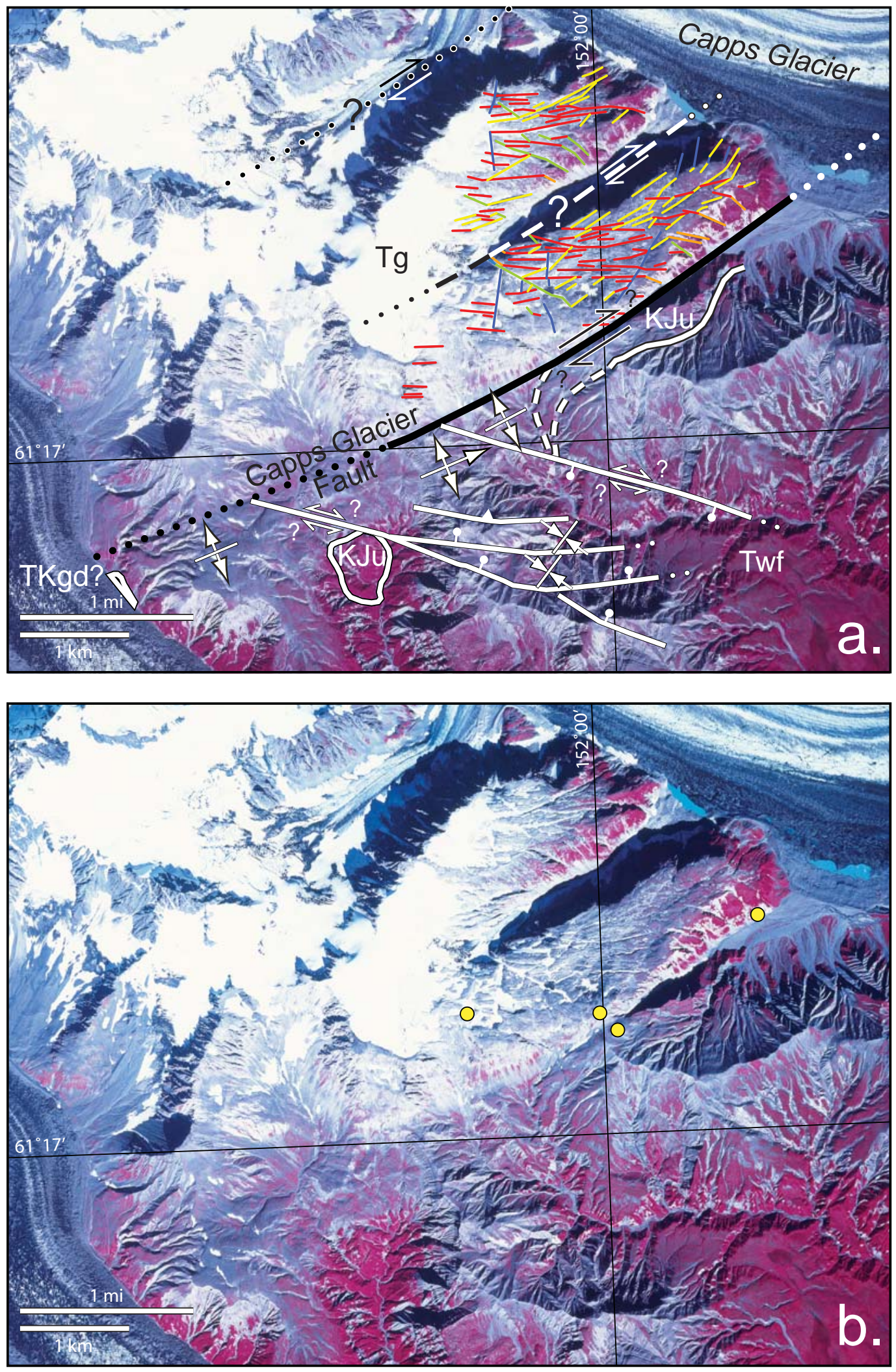


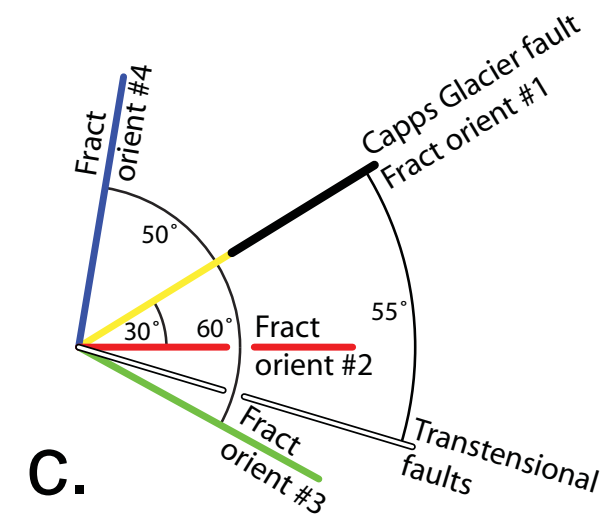

Figure 6 (page 6 and left). Interpreted (a) and uninterpreted (b) aerial photographs centered on the only documented exposure of the Capps Glacier fault (CGF) where Paleocene or older granitic rocks ( $\mathrm{Tg}$ ) to the northwest are juxtaposed against Tertiary basin fill (Twf), Cretaceous-Jurassic metavolcanics (KJu), and possibly Tertiary-Cretaceous granodiorite (TKgd) to the southeast. Thick black line corresponds to trace of CGF. Queried, dashed, and dotted lines in granite to the northwest of CGF depict potential subsidiary or en echelon faults. Colored lines refer to binned fracture orientations in granite (see also fig. 6c). White lines in lower portion of image represent approximate location of transtensional faults and fold hinge traces of deformed basin fill determined from field mapping and interpreted from stereo photographs. Approximate $\mathrm{Tg}-\mathrm{KJ}$ fault contact implies at least $3 \mathrm{~km}$ of right-lateral separation. Thermochronologic sampling locations depicted as yellow circles. (c) Fracture orientations interpreted from stereo photographs and qualitatively binned into four main fracture sets. Colored lines in diagram correspond to colors of fractures interpreted on aerial image (fig. 6a).

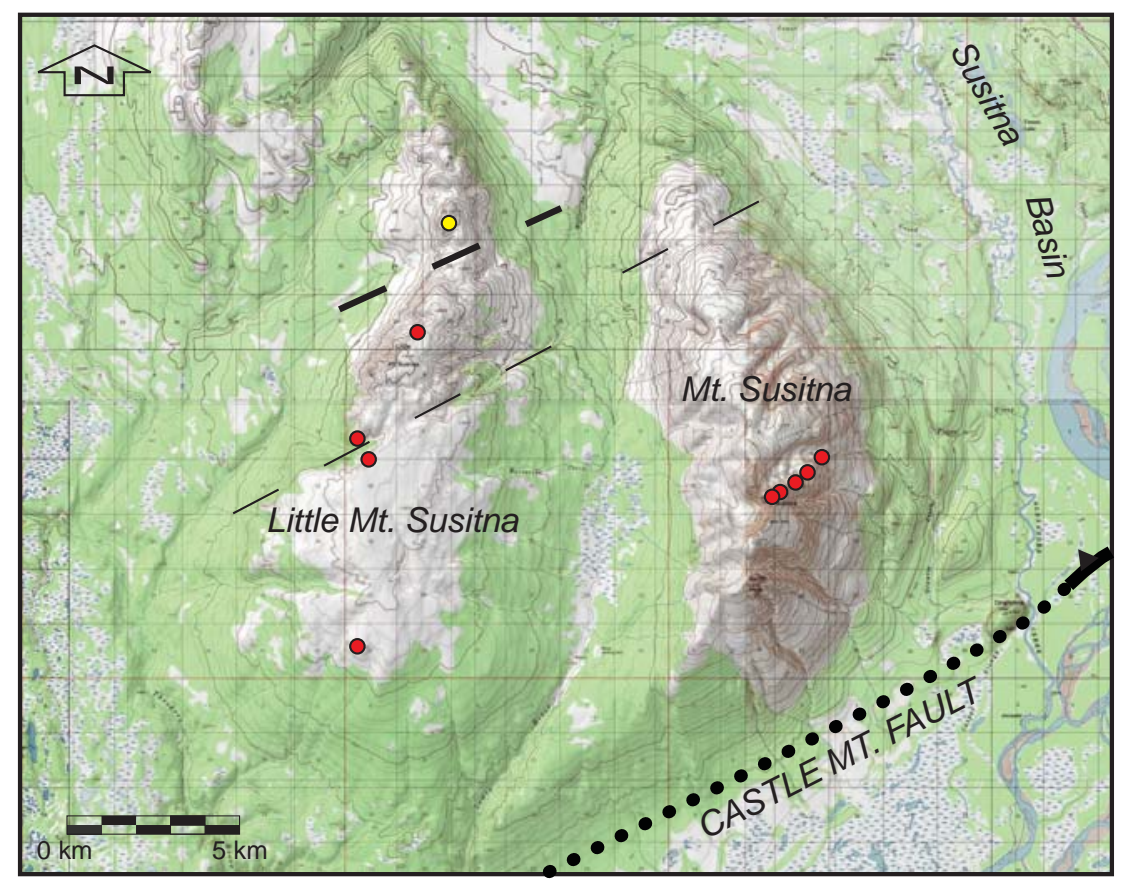

Figure 7. Topographic map of Mount Susitna area. Thin dashed lines represent approximate location of topographic lineaments across exposed Cenozoic-Cretaceous intrusive bodies. Medium dashed line represents a topographically-oriented boundary potentially separating texturally and compositionally different intrusive rocks as observed at outcrop and in hand sample. Red circles denote sample locations for thermochronologic analyses of medium-grained, foliated granitic granodiorite. Yellow circle indicates location of thermochronologic sample of texturally different, fine-grained, non-foliated granitic rock with highly shattered grains. Thick dotted and solid line represents the approximate location of the Castle Mountain fault. 


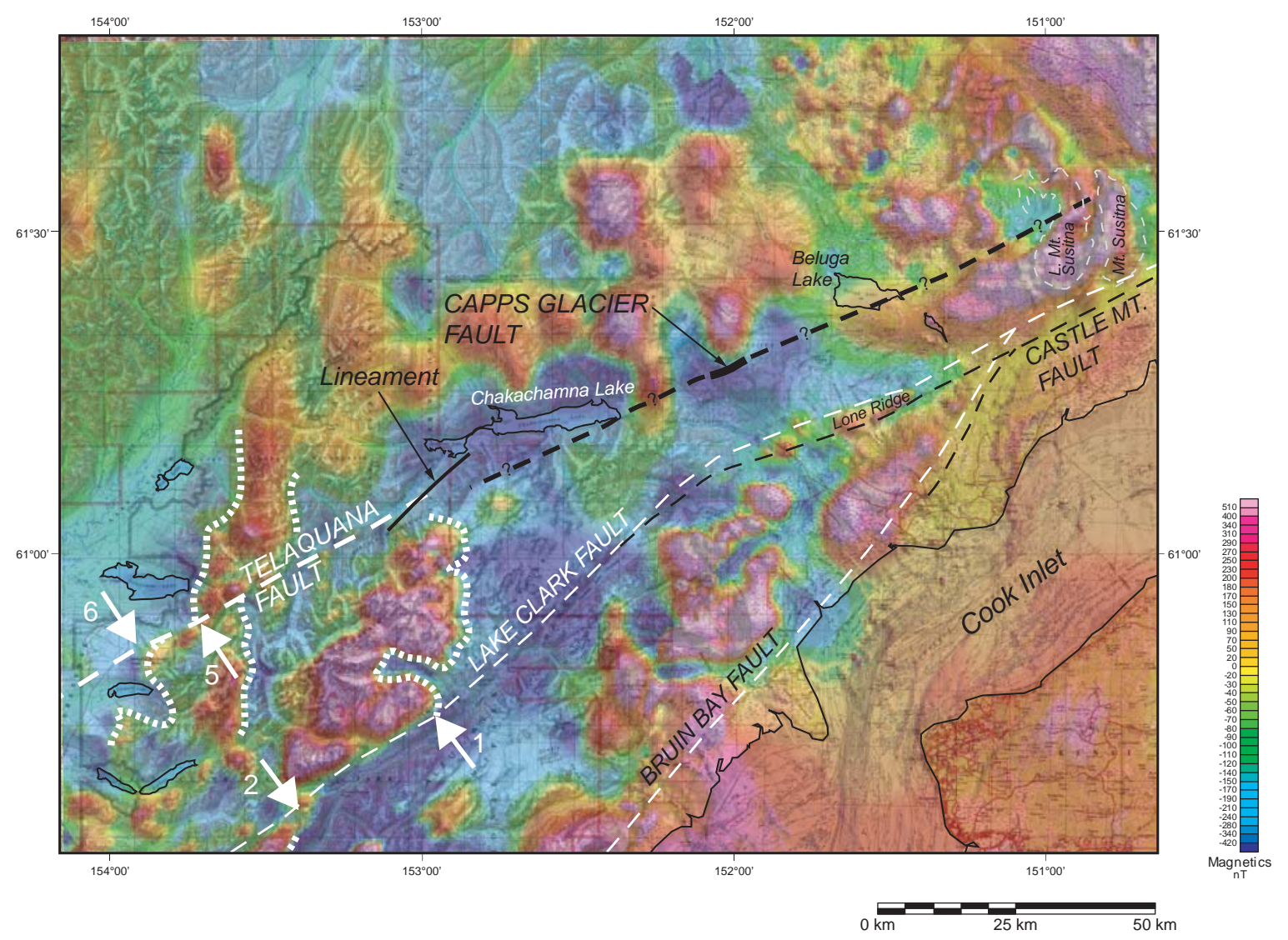

Figure 8. Aeromagnetic anomaly map adapted from Haeussler and Saltus (2004) of western Cook Inlet-southern Alaska Range superimposing topography and showing the interpreted position of the Telaquana fault relative to the projection of the Capps Glacier fault. Items in white are interpretations from Haeussler and Saltus (2004). Arrows 5 and 6 inferred to be piercing points of high magnetic anomalies suggesting $11 \mathrm{~km}$ of dextral motion along the Telaquana fault. Arrows 1 and 2 inferred to be piercing points of similar nature indicating $\sim 26 \mathrm{~km}$ of dextral motion along the Lake Clark fault. Thick solid black line represents the only identified exposure of the Capps Glacier fault. Medium dashed black lines represent the tentatively inferred southwestern and northeastern extensions of the Capps Glacier fault. Medium solid black line indicates the position of a prominent lineament evident in satellite imagery. Thin dashed black lines show the preferred approximate locations of the Lake Clark, Bruin Bay, and Castle Mountain faults based on geologic mapping of Barnes (1966), Detterman and others (1976), and Schmoll and Yehle (1987).

\section{REFERENCES}

Alaska Division of Oil and Gas, 2007, Annual Report: State of Alaska Department of Natural Resources Division of Oil \& Gas, p. 110.

Adkison, W.L., Kelley, J.S., and Newman, K.R., 1975, Lithology and palynology of Tertiary rocks exposed near Capps Glacier and along Chuitna River, Tyonek quadrangle, southern Alaska: U.S. Geological Survey OpenFile Report 75-21, 58 p., 1 sheet.

Barnes, F.F., 1966, Geology and coal resources of the Beluga-Yentna region, Alaska: U.S. Geological Survey Bulletin 1202-C, p. C1-C54, 4 sheets.

Calderwood, K.W., and Fackler, W.C., 1972, Proposed stratigraphic nomenclature for Kenai Group, Cook Inlet basin, Alaska: American Association of Petroleum Geologists Bulletin, v. 56, no. 4, p. 739-754.

Detterman, R.L., Plafker, George, Hudson, Travis, Tysdal, R.G., and Pavoni, Nazario, 1974, Surface geology and Holocene breaks along the Susitna segment of the Castle Mountain Fault, Alaska: U.S. Geological Survey Miscellaneous Field Studies 618, 1 sheet, scale 1:1,000,000. 
Detterman, R.L., Hudson, Travis, Plafker, George, Tysdal, R.G., and Hoare, J.M., 1976, Reconnaissance geologic map along Bruin Bay and Lake Clark faults in Kenai and Tyonek quadrangles, Alaska: U.S. Geological Survey Open-File Report 76-477, 4 p., 1 sheet, scale 1:250,000.

Finzel, E.F., Gillis, R.J., Ridgway, K.A., and LePain, D.L., 2009, Preliminary evaluation of basin margin exhumation and provenance of Cenozoic strata, Chuitna and Beluga rivers area, Cook Inlet forearc basin, Alaska: Alaska Division of Geological \& Geophysical Surveys Preliminary Interpretive Report, in press.

Haeussler, P.J., Best, T.C., and Waythomas, C.F., 2002, Paleoseismology at high latitudes: Seismic disturbance of upper Quaternary deposits along the Castle Mountain fault near Houston, Alaska: Geological Society of America Bulletin, v. 114, no. 10, p 1,296-1,310.

Haeussler, P.J., and Saltus, R.W., 2004, 26 km of offset on the Lake Clark fault since late Eocene time: U.S. Geological Survey Professional Paper 1709-A, 4 p.

LePain, D.L., Wartes, M.A., McCarthy, P.J., Stanley, R.G., Silliphant, L., Helmold, K.P., Shellenbaum, D., Gillis, R., Peterson, S., Mongrain, J., and Decker, P., 2008, Tertiary depositional systems in upper Cook Inlet, Alaska-Influence of fluvial style from reservoir geometries and stratigraphic trap potential: AAPG Annual Meeting Abstracts, v. 17, p. 119.

Magoon, L.B., Adkison, W.L., and Egbert, R.M., 1976, Map showing geology, wildcat wells, Tertiary plant fossil localities, K-Ar age dates, and petroleum operations, Cook Inlet area, Alaska: U.S. Geological Survey Miscellaneous Investigations 1019, 3 sheets, scale 1:250,000.

Reed, B.L., and Lanphere, M.A., 1969, Age and geochemistry of Mesozoic and Tertiary plutonic rocks in southcentral Alaska: Geological Society of America Bulletin, v. 80, p. 23-44.

Reed, B.L., and Lanphere, M.A., 1972, Generalized geologic map of the Alaska-Aleutian Range batholith showing potassium-argon ages of the plutonic rocks: U.S. Geological Survey Miscellaneous Field Studies 372, 2 sheets.

Schmoll, H.R., and Yehle, L.A., 1987, Surficial geologic map of the northwestern quarter of the Tyonek A-4 quadrangle, south-central Alaska: U.S. Geological Survey Miscellaneous Field Map 1934, 1 sheet, scale 1:31,680.

Swenson, R., 2003, Introduction to Tertiary tectonics and sedimentation in the Cook Inlet basin, in Dallegge, T.A., comp., 2001 Guide to the petroleum geology and shallow gas potential of the Kenai Peninsula, Alaska-A Field Trip Guidebook: Alaska Division of Geological \& Geophysical Surveys Miscellaneous Publication 128, 89 p., 1 disk.

Wolfe, J.A., Hopkins, D.M., and Leopold, E.B., 1966, Tertiary stratigraphy and paleobotany of the Cook Inlet region, Alaska: U.S. Geological Survey Professional Paper 398-A, p. A1-A29, 1 sheet. 